\title{
Facial Muscle
}

National Cancer Institute

\section{Source}

National Cancer Institute. Facial Muscle. NCI Thesaurus. Code C13073.

A skeletal muscle located under the skin of the face that is supplied by the facial nerve and controls facial expression. 